\title{
Consensus Modality in Nepal's Transition: Accommodating Parties and Shrinking Democratic Spaces
}

\author{
Rajib Timalsina
}

\begin{abstract}
Nepal is in a long political transition. This article focuses on the complex practices and concepts of political consensus in Nepal, and an effort is made to capture the political dynamics of different stakeholders of consensus politics with insights into the complex political reality. This article argues that the practice of consensus has contributed to easy resource distribution, containing overt violence, and accommodating diverse political parties, and made more progress in consolidating peace than in promoting democracy. Established democratic norms were monopolized by a few leaders in the name of consensus, sometimes even leading to political tensions. Thus, the consociation model falters in Nepal and the proper adoption of a democratic contestation model may be a solution for ongoing sociopolitical tensions.
\end{abstract}

Keywords consensus modality, democratization in Nepal, political accommodation, post-conflict peacebuilding, Nepal's transition

\section{Introduction}

Integration of former Maoist combatants back into society has brought the Maoist Armed Conflict to a close and Nepal's peace process can lay some claim to success by existing standards. But it still has flaws that have the potential to cause problems. Despite the moves towards peace, there are challenges at a time when the country has just emerged from armed conflict (Timalsina 2015). Against this backdrop, there has been a great deal of research analyzing Nepal's peace process, political transition, and conflict resolution process. Nevertheless, it seems that there are very limited assessments of the implications of political principles and theories on the entire Nepali political process. In this regard, the basic premise of this article is to examine the role, if any, played by the consensus principle in Nepal in the process of creating a stable, sustainable, and institutionalized 
democracy during the politics of peace over the last ten years. I try mainly to show the paradox of peacebuilding and democratization-contradictions between the principle of accommodation and majority rule, which actually refers to monopolization of the democratic process by leaders of a few parties. The specific examples in this paper are drawn mainly from the achievements, consequences, and complexities of the consensus theory in practice, and this article focuses its discussion on three major areas: political accommodation, resource distribution, and containing overt violence.

I am bringing the idea of "consensus," the principle adopted in peace politics for political accommodation, to the discussion in this article as it is a prominent part of Nepal's political culture. The term itself has been used often in Nepali politics over the last ten years. The concepts of sahamati (consensus) and sahakarya (working in collaboration) are not new in Nepal, but the way it has been used in Nepali politics over last couple of years is worth discussing. Mahesh C. Regmi (2002) discusses consensus and collaborative practices in Nepal's land tenure and cultural system. Though Regmi gives examples in this realm, most of the Nepali literature has not talked about the existence of consensus in politicallegal documents, even though it has been used in practice for a long time in various forms. The word consensus itself heroically entered Nepal's Constitution in the aftermath of the comprehensive peace agreement. The interim Constitution adopted in 2007 recognized consensus as fundamental principle for the governing process during the transition period. The "proportional representation system" was also introduced into the electoral system along with consensus as the governing modality to adapt social inclusion ideology into Nepali political culture. The terms consensus and proportional representation are closely related with the ideas of Lijphart $(2008,3)$ who uses the phrases "grand coalition" and "consociational democracy" for post-conflict peacebuilding, which largely focuses on power sharing and collaborative decision-making. In the case of Nepal, the idea of consensus has been defined, redefined, and modified according to the given political context and interest of the major political parties even though, from the beginning, consensus had a similar connotation with Lijphart's idea of consociational democracy.

This article concludes that the consociation model falters in Nepal and proposes an alternative suggestion of implementing majority rule with established due process after holding elections in this post-conflict society. Otherwise it will be difficult to establish a clearly acceptable decision-making system in such a political culture.

The findings reported in this article stem from a qualitative research project conducted by myself between 2011 and May 2015 where I interviewed political leaders, major decision-makers in the peace process, and civil society members. In addition to insights gained from these interviews, the arguments in this paper rely on available written sources in this area of inquiry and interviews with 
local and international experts on Nepal's political process. I developed codes to analyze the available information by establishing several themes, sub-themes, and categories.

This article is divided into six sections. The following section presents the analytical framework which I have used as theoretical base for conceptualizing the arguments in this article. The third section provides a very brief overview of the historical context of practicing consensus in Nepal. The fourth section investigates the rarely explored major achievements, as well as the consequences and complexities, of consensus practices in Nepali politics. This section has been limited to the subthemes of accommodation of parties, distribution of resources, and containing overt violence. The fifth section incorporates some narratives and counter-narratives on practicing consensus based politics. Before the concluding section, a brief discussion is given on different political positions throughout the phases of Nepal's transition period and roles played by international actors. The last section concludes the article by pointing out some of the key challenges and requisites for post-conflict peacebuilding and the consolidation of peace.

\section{Conceptual Framework}

"How can countries emerging from a conflict be supported on their path towards peace and democracy? Although this question has been the focus of recent attention, it remains unclear exactly what factors are critical to the success of a peace process" (Grävingholt et al. 2013, 1). Bringing in the arguments of Grävingholt et al., the dilemma of how to best support peace and democracy is clearly apparent when we look at what the academic debate perceives as being beneficial preconditions for the attainment of objectives, peace, and democracy during a post-conflict period. The political context also has huge impact on the modality which we adopt. The expected effects differ considerably; while a clear military victory is more likely to support a stable peace process, the exact opposite, namely a negotiated settlement, appears to be more conducive to successful democratization. A clear military victory silences opponents and creates an environment conducive to achieving the winner's goals. Negotiated settlements, like that in Nepal, are a pre-condition for the consensus framework, but securing stability becomes very hard.

In addition to the concept introduced by Grävingholt et al., I also reflected on the idea of "consociational democracy" coined and widely used by Arend Lijphart (1969; 2008). Lijphart $(2008,4)$ tries to define consociational democracy in terms of four basic characteristics: grand coalition, cultural autonomy, proportionality, and minority veto. For him, grand coalition and autonomy are the most crucial and other two are of lesser importance.

These arguments highlight the dichotomy between peace and democracy. 
As Nepal is a post-conflict country and moving forward from autocratic monarchial rule to a federal democratic process, both peace and democracy are two preconditions required for stability, economic development, and institutionalization. If we look at the root of these two preconditions, consensus lies at the base of peace and competition is a fundamental feature of democracy. In post conflict situations, we are faced with the dire need for both peace and democracy; but at the same time, the foundations of these two preconditionsconsensus and competition-rarely go side by side. Edward Mansfield and Jack Snyder (2013) concluded that democratization processes may result in instability in the form of intrastate or interstate war. According to them, introducing democracy too quickly in post-conflict societies is likely to result in conflict because of the absence of effective state institutions. So I use the dichotomous relationship between peace and democracy as well as basic characteristics of consociational democracy as an analytical framework for this paper.

\section{Emergence of Consensus in the Politics of Nepal}

Since the people's movement succeeded in bringing the Maoist armed conflict to an end and overthrew direct monarchial rule, Nepalese society has observed diverse socio-political tensions in different forms. Most of the political, social, economic, and cultural sectors have become fragile. And Nepal is a growing concern for the international community because of complications in its process of ensuring peace, stability, and economic progress. Helping fragile countries build effective state structures is a key task in development cooperation and the process presents a challenge to the international community (International Dialogue on Peacebuilding and Statebuilding 2011). At the same time, "political culture and social structure are empirically related to political stability" (Lijphart $1969,208)$. So we cannot separate the social and cultural context from the idea of stability. "One can read, or even write, about the events of the past without wanting to know why they happened" (Carr 1961, 113). The great thing in the thinking process is always asking why about new things or in new contexts and knowing the beginning. Looking into the past and posing questions based on different guiding principles is a good approach to understand the context better.

After the unification of small principalities, the Rana family in 1846 took control of Nepal in the form of hereditary aristocratic rule thus paralyzing the power of the monarch and limiting the royal family to a ceremonial role. The Rana family also cooperated closely with the British colonial rulers (Upadhya 2010,39). After the emergence of Nepal as a nation-state, the primary goal of the Nepali political system has always been to maintain the status quo, which meant the continuation of the delicate balance of power among various elite families. The first democratic movement in 1951 brought limited democratic change 
to the country and reestablished the role of the monarch in national politics through consultation with a few existing political leaders in some circumstances. The following years were fraught with instability and this led to a multiparty parliamentary election in 1959 under an interim constitution which retained most political powers in the monarch. Thus, political change which occurred in Nepal under the diplomatic midwifery of the Indian government was unable to ensure total political change (Joshi and Rose, 1966). Amid growing conflict between the palace and the elected government, on December 16, 1960, King Mahendra introduced the party-less Panchayat system and the main guiding principle was direct monarchial rule during this period. Three decades later, the Nepali Congress (NC), which was the main party up until this time, joined with leftist forces and organized mass protests in 1990 which established parliamentary democracy and majority rule by promulgating a constitution substantially reducing the monarch's power.

On February 4, 1996, the Maoists Armed Conflict started. In 2001, however, a new monarch came to the throne and he gradually dismantled the country's democratic structure by having Parliament dissolved in 2002, and then dismissing the government and declaring a state of emergency in 2005 (Grävingholt et al. 2013). Afterwards, the main political parties were alienated and subsequently united in a Seven Party Alliance. The alienation of established political parties one after another by the King created a conducive environment for these actors to come together despite their different ideologies. On the other hand, militarily, the Maoist and Nepalese Army both found themselves locked in a stalemate, and this led the armed rebels to moderate its political positions. The alienation process of the seven parties and the Maoist rebels realization that military victory was unlikely led to the Twelve Point Agreement in New Delhi, signed between the established seven parties and Maoist forces. In this agreement, both groups announced their plans to abolish direct rule of the monarch and form an all-party government. This was the point of departure for inserting consensus theory into Nepalese politics. The agreement opened not only the door for a new coalition between the rebels and the seven established political parties of that time, but also a formal starting point for consensus based political decision-making in Nepal.

The Twelve Point Agreement set the stage for weeks of mass anti-monarchy protests led by the newly formed partnership of the Seven Party Alliance and the Maoists. As a result of these protests, the King was forced to reinstate Parliament and the established parties returned to power. Following the success of the movements, the comprehensive peace accord was signed, and the interim Constitution of Nepal was promulgated by the restored Parliament. Both documents were the outcome of consensus modality and instrumental for peace and democracy in Nepal. The idea of consensus through a coalition government and a proportional election system for electing parliamentarians entered into Nepali politics via the adoption of an interim constitution in 2007. The signatories 
agreed to recognize, after several rounds of talks, the then rebels of the CPNMaoist group as the third largest political party in the interim Parliament, but the basis of the decision was the consensus among the Twelve Point Agreement signatories. That consensus-based agreement directly opened doors of the interim Parliament to seventy-three newly nominated Maoist leaders. For the first time in history, seventy-three people of a single political party became members of Parliament only on the basis of an understanding between eight political signatories of a previous agreement.

All these interim solutions were power-sharing arrangements which are often a useful means for creating stability in fragile post-conflict environments on the basis of minimum understanding and consensus. The consensus principle was at the heart of all decisions and practices that have followed since the Twelve Point Agreement in 2005 through the first national constitutional assembly election held in April 2008. The interim Constitution of 2007 formally accepted consensus modality as the method for electing the prime minister. The first constitutional assembly election was held in 2008 based on the interim Constitution. The following years witnessed many ups and downs in Nepali politics and governments were constantly formed and dissolved (ten governments in ten years). Each time there was a change in government, whether or not the consensus principle is required to logically end the peace process was a key issue of national politics.

\section{Achievements and Complexities of Consensus Modality in Peace Politics}

The violent conflict formally ended on November 21, 2006 with the signing of the comprehensive peace agreement between the government and the Maoists. This agreement ended the decade long armed conflict and, to some extent, defined what peace and democracy means in the Nepalese context. The agreement is the guiding document which shaped the principles, policies, and practices of Nepal's peace process. The peace process rested on four major pillars: (1) the rehabilitation and reintegration of ex-combatants; (2) reconstruction and post-conflict development; (3) national and local reconciliation; and (4) a new constitution and state restructuring. A few of these goals have been relatively realized, though seldom within the intended timeframe. "In many cases, reconstruction has deteriorated into a search for kam chalau (make do with what you have) alternatives rather than a planned process" (Timalsina 2016). The promulgation of a new constitution, a significant milestone in the peace process, was only recently achieved, but is still disputed. The peace accord envisioned reconstruction, reintegration of combatants, rehabilitation of conflict victims, and truth and reconciliation as tasks to be accomplished before an election, and an 
election was kept in the fourth phase of the peace process. The role of an election was not only to promulgate a new constitution, but also to institutionalize all of the agreed upon changes. As the process moved ahead, political actors failed to address the issues of conflict victims, initiate national reconciliation and reconstruction, and rehabilitate ex-combatants. So the political actors hurriedly decided to move onto the fourth component of the peace accord which was the election. That became a game changer for the politics of consensus in Nepal. The peace process in Nepal is still ongoing, even a decade after the signing of the comprehensive peace accord. However, the wording of the agreement was vague, with many details left to be decided during the political process that was to follow. The political process moved steadily and the relationships between the eight major political partners was healthy until the national politics entered into the next phase which is the post-first-constitutional-assembly election.

While focusing specifically on the specific achievements, complexities, and consequences after the introduction of the consensus principle into Nepalese political culture, there are numerous factors to be consulted. In the data analysis process, multiple emergent codes were developed, and later merged into three thematic codes. Based on that, I focus on three major points in this section which are directly associated with consensus based politics and practices in peace politics in Nepal: accommodating political parties, distribution of resources, and containing overt violence.

\section{Accommodating Political Parties}

The consensus principle itself starts with the involvement of multiple actors in the process. The act of political parties from different ideological backgrounds, representing different regions and diverse opinions, coming together and agreeing on certain principles is referred to as "political accommodation" in various academic studies. Here, political accommodation includes two broad components: power-sharing and inclusiveness. Key findings from scholarly articles show that political exclusion can trigger a relapse into civil war, while inclusionary behavior helps build peace in post-conflict societies (Grävingholt et al. 2013). So, it is obvious that more inclusive institutions are particularly more beneficial in post-conflict settings. The reason may be that this culture tries to address the main actors' fear of political marginalization.

Power-sharing is considered one of the beautiful parts of political accommodation and is crucial for a stable peace. Just as peace and democracy conceptually have a dichotomous relationship, the same trade-off holds for power-sharing agreements. According to Quinn, Mason, and Gurses (2007), successful power-sharing agreements between conflict parties contribute to stability by creating credible, stable, and mutually beneficial structures. Consequently, the condition helps to raise the cost of going back to war and retaining actors to the political structure, making it more beneficial. In the 
context of Nepal, the rebel force became the third largest party in the interim Parliament through a power sharing agreement in the interim Constitution. They also got an equal share in the government. Most of the decisions were made through consultations among major political parties who were sharing power. But examining the conditions carefully shows that these power-sharing agreements can have adverse effects on the consolidation of democracy because the powersharing between the eight major political actors of the 2006 mass movements did not recognize other actors, excluding them from participating in the governance process. The condition tended to produce a closed political arena that is not flexible enough to accommodate other possible actors. Furthermore, it supports the maintenance of wartime alliances and thus cements wartime cleavages in the new political system. It was clear that such power-sharing was creating clear divisions and preventing the establishment of a broader, heterogeneous feeling in society. Lijphart (2008) states that power-sharing in democracy may be beneficial for a deeply divided society. Nepal adopted the power-sharing framework based on coalition or consensus modality, but the practice was more diluted than the essence of the consociational form of democracy.

Second, inclusiveness has already become the heart of twenty-first century democratic practices. In post-conflict societies, supporting inclusiveness is another example of the dilemma between supporting peace and democracy at the same time. Several authors in both the peacebuilding and the democratization literature actually agree on the positive effects of inclusiveness. Udaya R. Wagle (2009) compares data covering the period from 1980 to 2003 from five historically and culturally homogeneous South Asian countries and suggests inclusiveness positively impacts democracy by minimizing economic inequality and sustaining democratic practices in the long run. Insights from the peacebuilding and statebuilding literature suggest that inclusive politics and institutions are one crucial element of establishing a sustainable peace. Takis Fotopoulos (1997, $\mathrm{X}$ ) states that "an inclusive democracy implies the abolition of the unequal distribution of political and economic power and the related commodity and property relations, as well as the hierarchical structures in the household, the workplace, the education place and the broader social realm.” Martina Fischer (2004) argues there are several prerequisites for war to peace transitions and gives continuous emphasis on governance, civil society, social welfare needs, respect for human rights, and democratic values in an inclusive manner. But including multiple parties also protracts the nature of conflict. Some new actors may have different viewpoints per their socio-political positions. Stephen John Stedman $(2000,178)$ has argued that the biggest source of risk for peace comes from spoilers-leaders and parties who believe the emerging peace threatens their power, world view, and interests use violence to undermine attempts to achieve it. The more parties involved in the process, the higher risk there will be for concluding the peace process. 
In the Nepal case, the seven political actors who were alienated by then King Gyanendra shared similar positions and interests. The alignment with the Maoist rebels also made a strong alliance against the absolute monarchy. But after the social and political movements in southern plains began, many new actors emerged on the scene, and many leaders from marginalized communities started raising their voices (based on an interview with an editor of a national daily in Kathmandu on February 13, 2015). This provided a wonderful opportunity for everyone to voice their opinions and for acquiring participatory democratic values. But at the same time, the involvement of multiple actors and multiple diverse demands stagnated the decision making process for a long time.

Overall, the practice of both power-sharing and inclusiveness made it very easy to manage the peace process. The success of the transition towards peace can be attributed to the consensus practice to some extent. At the same time, the time period for many tasks for the peace process took more than six years and some are still ongoing despite the original goal of completing the comprehensive peace accord within a six month period. In spite of many achievements during the peace process, many of which took longer to realize than originally planned, Nepal has faced major challenges too. Meanwhile, consecutive Nepalese governments have been characterized by instability and struggles for political control, reflecting a lack of agreement among the main parties over the future of the political system. For a long time, the country stagnated due to the constitution drafting process (based on interview with former Minister of Peace and Reconstruction on July 21, 2015). Six years later, the constitution assembly promulgated a constitution which created many controversies and debates. Regarding the new constitution, social tensions emerged in the southern plains and still that tension has not been solved. In addition, issues such as the effective implementation of the Truth and Reconciliation Commission (TRC) still need to be resolved, but a consensus has not been reached among parties for the modality of implementation yet. And we also need to carefully think about an example from Nepal where, in the name of consensus, the decisions were hijacked from the democratic process and imposed by the top five leaders, which is risky and different from what inclusive theory actually suggests. In the words of Catinca Slavu (2012, 232), holding an election right after the initiation of a peace process frames two circular paradigms: one is that the election will sustain the necessary momentum for the peace process by maintaining trust between parties collaborating for democracy, and the second is that holding an election before a certain level of stability exists and granting the traditionally marginalized communities the freedom to elect their own representatives was prone to opening up new forms of conflict.

\section{Containing Overt Violence}

Based on all the experiences and lessons of the protracted peace process of Nepal, the major achievement of the last decade is that the violent conflicting party was 
converted into one of the major political parties of Nepal through negotiations among the political leaders. The decade long armed conflict was stopped and the rebel force was dismantled peacefully. Despite the many flaws of the Nepali peace process, the peaceful management of ex-combatants can be considered a success. The successful management of the rebels has prevented direct clashes and casualties. But so many small armed groups proliferated throughout the southern plains after the Madhesh Aandolan. Many people see the advantages of forming a rebel group after witnessing the financial and political benefits reaped by the Maoist rebels during the post-2007 process. At the same time, many other new identity based social movements were initiated. Though there were many protests and movements with some human casualties, it was not on the same scale as incidents during the Maoist Armed Conflict. Thus, containment of direct and overt violence can be attributed to the consensus policy adopted in postconflict Nepal. At the same time, that claim leads to the question of whether or not overt violence can be contained or stopped when structural or latent violence is not addressed. The spirit of the comprehensive peace accord was to stop both the overt and latent violence in Nepal, but the overall agenda of the Nepali peace process was shaped by reintegration or rehabilitation of Maoist ex-combatants.

There is no specific example of how the political actors attempted to address structural conflicts. The example of ex-combatants illustrate the basic idea of how it helped contain violence and also opened room for corruption. The former coordinator of the Secretariat for Supervision, Monitoring, and Rehabilitation of Maoist Combatants explained the major processes during an interview on July 9, 2015 in Kathmandu. In 2007, both the government and rebels requested that the United Nations (UN) monitor and supervise the ex-combatants. Ex-combatants were kept in twenty-eight cantonments. After the completion of the UN mission in Nepal, the role of supervising and monitoring was assigned to a team of Nepali experts from both the state security forces and Maoist Army under the control of the Nepali government. The consensus between the government and rebels made the job of managing the ex-combatants very easy. The Maoists claimed 19,602 excombatants were residing in the cantonments and so the government provided monthly financial support for food and basic services for that number. The Maoists did not allow for verification until 2011. When an expert team re-verified ex-combatants in 2011, they found only around 15,000 ex-combatants living in the cantonments. On the one hand, a huge number of rebels was contained inside the cantonment peacefully, while on the other hand a massive amount of money and resources was misused by the Maoists by falsifying the number of excombatants.

\section{Distribution of Resources in Post-Conflict Set-up}

The consensus between political parties made it very easy for resource sharing as well. In the interim Parliament, the composition was restored based on 1999 
election results and the new Maoist party was given the third rank by consensus. The resources of the state were divided based on party position and the number of members in Parliament. Major political appointments were also conducted using the same principle. And representatives from all parties (of course only including the eight partnering political parties of the 2006 movement) were placed in government departments and agencies where the major decisions over resource distribution happens. From the center to local level, all resource distribution bodies were filled with representatives from all eight political groups.

The newly formed government, after the successful of people's movement, established a new arrangement called All Party Mechanism at the center level. Here, the All Party Mechanism was the term given by the government to a team of eight leaders who were supposed to assist the government with major political decisions. Article 38 (1) of the 2007 interim Constitution explained that the All Party Mechanism includes only the eight parties who were the signatories of the Twelve Point Agreement which include the seven political parties-the Nepali Congress, Communist Party of Nepal (UML), Nepali Congress (Democratic), Janamorcha Nepal, Nepal Sadbhawana Party (Anandidevi), Nepal Majdur Kisan Party, Samyukta Bam Morcha Nepal—and the Communist Party of Nepal (Maoists).

This made decision-making very easy, but it also led to no elections at the local level. All the major parties enjoyed privileges through the All Party Mechanism and they never realized the need for any local elected bodies. This led to a situation at the local level where there is no locally accountable body. And many citizens' grievances remain unaddressed. In the villages, two parallel units were formed: Local Peace Committees to deal with issues related to the peace process, and the All-Party Mechanism to guide development work, allocate the budget, and work in place of a village council. Both were based on the consensus modality. Representatives from political parties were nominated by top leaders in those committees. The local peace committees were very important bodies in concluding the peace process, but the committees were less attractive bodies for local political leaders. Most of time, they were engaged in the All Party Mechanism which was lucrative as it dealt with resource mobilization. Very few issues of debate were reported in the All Party Mechanisms as the political leaders were champions of resource distribution per their representation in Parliament. The only cases reported involved the exclusion of other parties, corruption, issues of accountability, and ignorance of local demands. There may have been misconceptions that citizens cannot make a difference unless power holders also want to realize change. But even the 2006 movement has shown that people power has the capacity to create political will where it did not exist and apply pressure on recalcitrant institutions and governments to take action (Beyerle 2014, 16).

"The European modernization process was shot through with wars; indeed, 
there is strong case to be made that the present European nation-states, now living peacefully within the confines of the European Union, were born out of warfare in which there basic state structures were shaped" (Koponen 2010, 41). Looking into past European examples, the conclusion can be drawn that the basic pre-requisite for peace is participation, even though a country is emerging from war. Participation of all sectors of society is very important for both the peace process and proper resource mobilization. That is why the consensus principle is highlighted in post-conflict societies like Nepal. This means not only including different societal elites (horizontal inclusiveness), but also gaining the participation of the public at large at different levels (e.g. national and local) to ensure vertical inclusiveness (Brown and Grävingholt 2011). Nepal's peace and democratization process has focused predominantly on central government politics (based on interview with former Minister of Local Development on July 13, 2013). And most of the center level leadership roles have been dominated by high-caste-hill elites. While looking at past migration rates, the majority of migrants from the hills to Terai and other parts to Kathmandu are high-caste people (Gaige 1975).

Building strong local institutions to support peace and democracy throughout the country, and thus strengthening the resilience of the postconflict process, has received much less attention despite it being a very crucial task for the peace process. The consolidation of peace was very weak in terms of reconciliation and democracy at the local level. Involving the wider population is crucial to the success of post-conflict processes. A peace process can be sustainable only if relevant actors at all levels feel represented. Stability at the local level has been achieved, but democratic practices are not being developed. At the same time, the center level held two national elections, but is very unstable. The Local Peace Committees, for example, include representatives from marginalized groups and civil society. However, interviews revealed that their involvement is often on paper rather than in practice.

\section{Narratives and Counter-narratives on Consensus based Politics}

As mentioned before, Lijphart (2008) has identified four basic characteristics of consociational democracy: grand coalition, cultural autonomy, proportionality, and minority veto. There are also counter-narratives about consensus based processes in Nepal which were and are still used by democratic parties. The practice of coalition government between top political parties sometimes undermines the essence of a grand coalition. This allows a new framework where top leaders practice authoritarian rule through the eight party alliance similar to the absolute monarchy. The only difference is rule by many rather than rule by one, and a gang of eight political parties uses the rhetoric of consensus to 
justify their acts and their ruling of the country (based on an interview with one Madhesh based leader on August 7, 2014 in Kathmandu). This consensus based ruling system clearly undermines minority rights and the legitimacy of Parliament. In other words, it can be said that democratically elected parties used a consensus framework to hijack democratic practices even though most of the characteristics of Lijphart's framework were experimented with in different forms in Nepal. This is related to the argument that different forms of consociational democracy do not work equally well and should not be equally recommended to multi-ethnic and multi-religious societies (ibid., 4). Proportionality based elections are only used to rank the political parties. Then, the leaders of the political parties became the decision-makers and Parliament became only a forum to ratify their decisions. The interesting thing is even leaders who lost an election also participated in political negotiations and became key players in major decisions. Most of the major decisions of the country are made outside of Parliament by top leadership. And those decisions were ratified by Parliament. Even, the Constitution was promulgated in last two days of the constitution assembly without proper discussions and consultations with members of the assembly. The decisions were made by the top four leaders and then Parliament was used as the place for the formal ritual of ratifying the document. Though there was an election and the body of Parliament is an elected one, they were never sovereign in the decision-making process because the top leaders of parties were not even members of Parliament though they impose decisions through the so called practice of consensus modality.

The wording in the comprehensive peace accord, interim Constitution, and now the new Constitution is so vague that political actors interpret clauses of those documents per their individual interests. The consensus concept was always questioned by political actors themselves after the 2008 election. The top three parties in the 2008 election secured almost 85 percent of the seats in parliament. And the fourth most powerful bloc in Parliament consisted of representatives from the regional political parties in the south. The top three political parties were partners from the previous eight party alliance. They always undermined the role of the fourth most powerful bloc. Now, for the top three political parties, consensus only includes themselves and they comprise an absolute majority in Parliament. For the regional parties and other small parties, consensus means inclusion of all the political parties in Parliament, or at least the top seven to nine parties which comprise almost 97 percent of the seats. But during government formation, a simple majority was decisive and parties began to understand that even a simple majority can be decisive per the democratic principle. So, each party defines the concept of "consensus" in various ways in different contexts based on if it is included or excluded from the decision-making process. The constitutional provision clearly envisions consensus as the basic premise for governing the country during the transition period. Article 38 of the interim 
Constitution of Nepal $(2007,17)$ set criteria for the formation of government on the basis of consensus which reads as:

Article 38. Formulation of the Council of Ministers

(1) The Prime Minister shall be selected by political consensus and the Council of Ministers shall be formed under the chairpersonship of the Prime Minister. Explanation: For the purpose of this Constitution "political consensus" means the political consensus reached between the seven political parties - Nepali Congress, Communist Party of Nepal (UML), Nepali Congress (Democratic), Janamorcha Nepal, Nepal Sadbhawana Party (Anandidevi), Nepal Majdur Kisan Party, Samyukta Bam Morcha Nepal - and Communist Party of Nepal (Maoist) on 22 Kartik 2063 (November 8, 2006).

(2) If consensus cannot be reached pursuant to clause (1), the Prime Minister shall be elected by a majority of two-thirds of the members of the Legislature-Parliament.

(3) The structure of, and allocation of portfolios to, the Interim Council of Ministers shall be determined by consensus.

But over the last ten years, the constitution was amended more than ten times and that particular article was amended twice and re-defined multiple times. The second amendment of the interim Constitution allowed political parties to form a government by a simple majority. This amendment was created because the political situation of the country changed totally after the 2008 election. It became more difficult for the eight party alliance to make decisions independently from other political parties because of the presence of various new forces after the election. Thus, the consensus practices were challenged several times by dissatisfied and marginalized groups. These groups were being vocal regarding minority rights and self-determination. Though the proportional election system to some extent has addressed these voices by making Parliament more inclusive, in the name of coalition and consensus, many rights and the sovereignty of Parliament have been curtailed by top leaders. Jude Lal Fernando $(2013,223)$, in relation to the Tamil movement for self-determination, notes a missed opportunity. The history of polarization has much to do with the decisionmaking process. And top leaders seemed more focused on extracting benefits out of the peace process than using consensus modality for improving the lives of the people. This can be dubbed a "missed opportunity" to use the words of Fernando.

The consequences of the adoption of the consensus framework are not limited only to political accommodation, resources sharing, and containing violence, but also raise many questions regarding the whole political process. The 2008 elections were a crucial step in the peace process, despite perhaps not meeting the highest democratic standards, and were overwhelmingly viewed as a very positive event and a milestone for the peace process. All the political actors first agreed to set a sequence for the peace process, and the election was kept as the last pillar of the peace process. But in practice, the election was the first to be 
implemented instead of ex-combatant management, victim relief, reconstruction, and transitional justice. The 2008 elections are a critical juncture which marked the downward trend of the consensus framework. Elections are always considered one very important element of democracy given that it allows for peaceful competition between the political actors. However, elections also create distance between political parties which is not necessarily conducive to stability. While substantial successes was achieved in the Nepalese democratization process, it continues to suffer from instability and an inability to completely consolidate the transition. For the Nepali leaders, elections were merely a practice of the Weberian concept of power.

Though the consensus modality in the center was broken after the election, a majoritarian government was formed and led by rebel leaders leaving other major political forces in the opposition. The All Party Mechanism and consensus practices in the resource distribution modality was continued in a similar fashion. The local mechanism was expanded to accommodate representatives of new political parties elected to Parliament after the 2008 election. Although local elections could have potentially solved a number of problems, leaders did not engage effectively in this regard. There have been no elections at the local level for the last seventeen years and this has resulted in stability at the local level, but service delivery and accountability are worse than ever (based on interview with former election commissioner on April 10, 2015 in Kathmandu). The All Party Mechanism was established as a new type of mechanism which is a good example of a consensus framework at the grassroots level and good for the peace process over the short term. In long run, however, those practices became counterproductive when employed in the context of democratization. These mechanisms at the local level are inclusive as well as a good example for power-sharing, accommodating diverse political parties, and following consensus modality; but they are not democratic and come with the possibility of institutionalizing corruption and unaccountability. Despite many allegations, consensus based political practices were more sustained at the local level compared to the central level. The first government after the successful people's movement was based on the consensus principle. But, following governments were formed through a simple majority in Parliament. Political decision-making during the peace process was so difficult and stagnated because of the lack of consensus. And that kind of hurdle became the reason for frequent government change. Each time there was some difficult situation in political decision-making, oppositions and other parties called for consensus based politics and consensus based government. In consequence, the political parties failed to form consensus based governments and majority based governments continually replaced another until ten governments had been formed in ten years. 


\section{Political Positions and Administrative Capacity in Nepal's Transition}

The consensus principle was highly effective up until a national election was held. When elections, a component of democracy, were introduced in 2008, the parties were divided along with their power positions in Parliament. The disagreement among the parties led to the failure of the first constitutional assembly despite a two year extension of its term. Though a proportional representation system was utilized in elections, the practice of consensus became problematic. Nepal's transition can be divided into five broad phases with different features.

The first phase starts right after the success of the nonviolent movement of April 2006 and lasts until the signing of the comprehensive peace accord in November 2006. The Seven Party Alliance was the main decision-maker and the consensus framework applied to their decision-making process. And then the Maoist rebel force supported them as they had not yet come to openly participate in politics but were strategically allying with the Seven Party Alliance against the monarchy.

The second transitional phase starts after the signing of the peace accord and proceeds until the beginning of the first constitutional assembly election. The rebel force negotiated with the Seven Party Alliance and joined the interim Parliament and the consensus government. The now eight parties started negotiating with one another and decided on most state affairs through consensus based on the interim Constitution promulgated as a byproduct of their negotiations. Right after the adoption of the interim Constitution, uprisings by marginalized groups in the South (the Madhesi) brought a whole new set of actors to the political scene in 2007 and compelled the government to amend the Constitution and guarantee a federal democratic nation.

The entirety of the first constitutional assembly should be considered the third phase of Nepal's transition. After the elections for the Constituent Assembly, the process suffered additional setbacks, culminating in May 2012 in the dissolution of the Constituent Assembly, which had not managed to deliver a constitution in four years. The 2008 election also changed power roles, introduced more than twenty-five political parties into Parliament as new actors, and changed the power relations of the initial eight signatories of the Twelve Point Agreement which was basis for the people's movement. The new context contributed toward breaking the interim coalition which was set up through consensus. When, the electoral results were announced, the political dynamics completely changed. Though there was no clear majority in Parliament, discomfort arose between the parties as the former rebel force became the largest party in Parliament after the election, up from its third place rank in the interim Parliament. The new Parliament failed to elect a prime minister by consensus in the spirit of the interim Constitution. After a long deadlock, the consensus principal was 
broken and CPN-Maoist chairperson Pushpa Kamal Dahal (Prachanda) was elected Prime Minister of Nepal by a majority of the votes in Parliament. This resulted in the second largest party, which led the interim government and the whole peace process, not being in the government. That led to a situation where the entire political process was paralyzed by four to five major leaders and their power bargaining, neither being able to decide by majority rule nor succeeding in coming to consensus based decisions.

During this period, the country observed a new wave of social movements where many identity based political groups emerged and became vocal in national politics. Most of the time the tussles between political leaders and the new political actors from identity based parties overshadowed national politics. Different parties which were engaged in the consensual political process represent different socio-political and ethnic constituencies. In the southern plains, regional parties with a strong voice for Madhes (an identity for those from the southern part of the country) provinces have grown large, and, in the east, Limbuwan (an ethnic-identity based group from eastern side) emerged as a vocal group. Similarly, in the western part of the country, regional, cultural, religious, and ethnic identity based groups speaking for their own provinces based on their communal identities have entered the scene. All these sometimes vocal and sometimes overlapping demands, as well as diverse interest groups, created different political dynamics.

The fourth transitional phase began with the second constitutional assembly election and ended with the promulgation of the new Constitution. Unlike the first constitutional assembly, the Maoist party was the third largest party in the second assembly. The identity based parties' share of seats decreased while at the same time rightist parties who support monarchy and the Hindu religion became major players in Parliament by securing the fourth largest number of seats. The new situation raised the very important question of whether or not all political positions could be accommodated. The rebels and other established political parties refused to consider the return of monarchy in any form after the success of the people's movement of 2007. The new election results compelled political actors to think once again about the parameters that determine the limits of consensus. The eight party alliance started to work with all political parties on a situational basis, but no role was given to the monarch during political negotiations. Though identity based groups became a bit less vocal in parliament, the southern Madhesi group started protests in the southern part of the country, boycotted the ongoing drafting of a new constitution, and blamed the three major political parties for isolating marginalized voices and hijacking the democratic process. All these groups closely observed the consensus based process for major political decisions up until this point, but during this period the three major political parties started to emphasize their majority and did not give attention to the demands of the dissatisfied groups. These major political parties then moved 
to suspend the established parliament rules and rushed to promulgate the new constitution.

The next phase of the transition started with the adoption of the new constitution. India stated its dissatisfaction with the new developments in the country, and Nepal faced an undeclared border blockade for more than four months in late 2015. The interim government was replaced by a new interim government led by a Maoist leader once again, and the opposition party was accused by the government of being pro-India. At the same time, the government blamed the opposition for not cooperating with the government on implementing the new Constitution. The southern regional groups are still protesting in different manners and asking for constitutional amendments. So, the internal politics of the country has arrived at a crossroads of different sociopolitical tensions. The country has agreed to adopt a liberal democratic process in principle, but none of the groups are ready to accept results of such a process. People view decisions made by parties as having often been decided on the basis of power without clearly following democratic guidelines. So, despite political actors agreements to establish rule of law and conduct politics based on liberal democratic practices, major decisions often bypass democratic practices and Parliament is regulated to a rubber stamp function.

In addition to understanding the domestic political situation, analyzing international politics, particularly focusing on Nepal's neighbors, is crucial. The notion that a country's neighborhood plays an important role in democratization as an external factor is the subject of academic debate. Grävingholt et al. $(2013,15)$ further argues that the past two decades have seen an expansion in international mediation and a larger number of international actors involved in transition processes. The role of neighbors is extremely important in the Nepalese case because Nepal is a landlocked country between the emerging powers of China and India. Both countries share strong ties with Nepal in terms of economic, geopolitical, social, cultural, and communication linkages. The power-relation tilts more towards India because Nepal relies on India for access to its markets and the sea. The two countries also have close ethnic, cultural, and linguistic linkages. Because of the geographic terrain, China has less influence through people to people contacts whereas India shares an open border and people move freely between the two countries. China is much more cautious with Nepal because Nepal shares its northern border with Tibet, a sensitive region in China. So, both the countries have diverging security interests more than anything else. Grävingholt et al. (ibid.) argues that China, for its part, does not play such an important role in Nepal, although it has significantly increased its engagement since the comprehensive peace accord was signed in 2006 for security reasons. While China is a highly autocratic country, India looks at Nepal from a security perspective and possibly as a supplier of natural resources, not having any will to expand democracy through its foreign policy. So Western 
donors are the only external actors in Nepal seeking to support democracy. But neither geographic proximity nor clear historical ties exist between Nepal and Western donors. So, the linkage between the West and Nepal is weak. That's why Nepal is focusing more on stability and peace rather than adopting democratic values. This does not mean Nepal is trying to be autocratic. Of course this political transition is a journey from authoritarian rule towards a democracy. But political actors have made more progress in consolidating peace than in promoting democracy.

Before concluding this paper, I would like to briefly discuss administrative capacity and institutionalization of the bureaucracy. Many times I have observed that roles of different state organs are mismatched. The power sharing practices between the three major political parties have paralyzed almost all state agencies over the last decade. Universities, commissions, state agencies and departments, and even the judiciary are affected by quota systems for the recruitment of representatives from the three political parties. Rather than establishing such a system, the established parties are enjoying the benefit of misusing the recruitment norms to create space for their cadres.

A more interesting example may be the role played by the executive and legislative branches. Parliament first authorized a development fund worth NPR\$ 1 million to spend for developmental activities in their constituencies. In subsequent years, the amount was increased to NPR $\$ 5$ million and NPR $\$ 50$ million respectively. Now, members of parliament are busy selecting projects and approving the development work by themselves rather focusing on policymaking and legislating. They consider this to be power because they can directly influence people and specifically work to benefit their own cadres. So they are less interested in policymaking. On the other hand, the country lacks laws and regulations in many sectors. Local bodies have not had elected representatives since 2002, and all these responsibilities have been given to bureaucrats. Now, most offices are being operated based on the directives and rules drafted by bureaucrats themselves. Many of them are incompatible with statutes and the Constitution. Because of the partisan politics and political quotas in every sector, people rarely get the chance to raise their voice against this mismanagement. The 2007 Madhesh based movement sought not only to end the monarchy but to establish federal democracy. Now, there is a democratic system in principle, but the actual practices of the political actors are contributing toward shrinking civic and democratic spaces. Different forms of syndicate and high level corruption, as well as complex bureaucratic channels, have made the country more undemocratic which is against the common will expressed in people's movement in 2006 and other subsequent movements and elections. 


\section{Conclusion}

Numerous political questions remain unclear during the peace process in Nepal and the national politics revolved around the how to practice the politics of consensus. The experimental model of consensus politics in Nepal made the country more fragile. On the one hand, the peace process was started with the aim to restore democracy and sustain it, but the last ten years have witnessed democracy being hijacked through isolation of the people and elected representatives from major decision-making processes. Most of the time a few top leaders were making decisions by bypassing Parliament and authentic decision-making bodies which furthermore weakened the institutionalization of the democracy. This article has examined the adoption of consensus modality in Nepal's political process as a means to solve various issues and institutionalizing recent changes, namely secularism, federalism, and democracy. In terms of peace and democracy, inclusive representation and participation of different social groups in decision-making is highly limited. The political system in Nepal lacks a legitimate and empowered representation for local needs and interests. The top leadership always undermines inclusive representation in Parliament and it was only used as a bargaining chip in the power-sharing modality. In the name of consensus, democracy was threatened many times in many ways by a handful of leaders, thus it is not that different from the authoritarian rule of a monarch. Nepal is dealing with socio-political tensions because of protests that express disagreement in the process of constitution making and want their demands incorporated into the political-legal documents.

It can thus be concluded that the Nepalese case demonstrates a focus on stability may be necessary and useful in post-conflict settings, particularly during the early stages of the process. It can also be claimed that, however, democratization processes should not generally be delayed, as they are often necessary to make peace sustainable. But moving more quickly towards setting up democratic institutions may hinder the consolidation of peace. So, the sequence most beneficial for society is adopting democratic practices, followed by solving major stagnations in the peace process, and then institutionalizing both the democratic structures and peace dividends. Thus, this article finds that the consociation model falters in Nepal. At the moment, the alternative solution is to adopt a democratic contestation model properly. In my opinion, only a system of giving proper decision-making space to elected representatives can provide an inclusive way for solving the ongoing socio-political tensions through agreed upon norms. Over the past ten years, our political decision-making process was more based on influential leaders' discretion than setting up a formal democratic decision-making process. If we continue down the same path, there will be more complexities because of the lack of a precise and authentic decision-making 
system to represent the people's voice. Failing to consolidate proper democratic values in political practice might lead to more dissatisfaction and the political environment of the country will again relapse into authoritarianism.

\section{Acknowledgements}

This paper was presented at the workshop on "Post-conflict Peacebuilding and Democratization in Asia: The Role of Democracy" hosted by the Institute for Peace and Unification Studies, Seoul National University, on August 25-26, 2016.

\section{References}

Brown, Stephen, and Jörn Grävingholt. 2011. From Power Struggles to Sustainable Peace: Understanding Political Settlements. Paris: OECD.

Beyerle, Shaazka. 2014. Curtailing Corruption: People Power for Accountability \& Justice. London: Lynne Rienner Publishers.

Carr, Edward Hallet. 1961. What is History? New York: Vintage Books.

Fernando, Jude Lal. 2013. Religion, Conflict and Peace in Sri Lanka: The Politics of Interpretation of Nationhoods. Zurich: Lit Verlag Gmbh \& Co.

Fischer, Martina. 2004. Recovering from Violent Conflict: Regeneration and (Re-) Integration as Elements of Peacebuilding. Berlin: Berghof Research Center for Constructive Conflict Management.

Fotopoulos, Takis. 1997. Towards and Inclusive Democracy. London: Cassell.

Gaige, Frederick H. 1975. Regionalism and National Unity in Nepal. Berkeley: University of California Press.

Grävingholt, Jörn, Bendfeldt, Lennart, Berk, Linda, Blos, Yvonne, Fiedler, Charlotte, and Mross, Karina. 2013. "Struggling for Stability: International Support for Peace and Democracy in Nepal." German Development Institute, Discussion Paper 27/2013. https://www.die-gdi.de/en/discussion-paper/article/struggling-for-stabilityinternational-support-for-peace-and-democracy-in-post-civil-war-nepal/ (accessed December 09, 2016).

International Dialogue on Peacebuilding and Statebuilding. 2011. "A new deal for engagement in fragile states." November. https://www.pbsbdialogue.org/media/filer_ public/07/69/07692de0-3557-494e-918e-18df00e9ef73/the_new_deal.pdf (accessed May 10, 2017).

Joshi, Bhuwan Lal, and Leo E. Rose. 1966. Democratic Innovations in Nepal. Berkeley: University of California Press.

Koponen, Juhani. 2010. “The Security-Development Nexus: State Fragility and State Building." In Exploring the Security-Development Nexus, ed. Henni Alava. Helsinki: Ministry for Foreign Affairs of Finland.

Lijphart, Arnold. 2008. Thinking About Democracy: Power sharing and majority Rule in theory and practice. New York: Routledge. 
Lijphart, Arnold. 1969. “Consociational Democracy." World Politics 21 (2): 207-225.

Mansfield, Edward D., and Jack Snyder. 2007. "The sequencing 'fallacy.” Journal of Democracy 18 (3): 5-9.

Regmi, Mahesh Chandra. 2002. Nepal: An Historical Miscellany. New Delhi: Adroit Publishers.

Quinn, Jason Michael, T. David Mason, and Mehemat Gurses. 2007. "Sustaining the peace: Determinants of Civil War Recurrence." International Interactions 33 (2): 167-193.

Slavu, Catinca. 2012. “The 2008 Constitution Assembly Election: Social Inclusion for Peace." In Nepal in Transition: From People's War to Fragile Peace, eds. Sebastian von Einsiedel, David M. Malone, and Suman Pradhan, 232-254. New Delhi: Cambridge University Press.

Stedman, Stephen John. 2000. "Spoilers Problems in Peace Process". In International Conflict Resolution After the Cold War, eds. Paul C. Stern and Daniel Druckman, 178224. Washington, D.C.: National Academies Press.

Timalsina, Rajib. 2015. "Bringing Armed Group into Parliamentary Processby Nonviolent Means: Existing Challenges of Nepal." Thammasat Review 18 (1): 47-68.

Timalsina, Rajib. 2016. "The Promise and Perils of Aid: The Role of the Nepal Peace Trust Fund (NPTF) Framework in Facilitating Post-Conflict Development in Nepal." Asian Journal of Peacebuilding 4 (1): 115-135.

Upadhya, Sanjay. 2010. “A Dozen Years of Democracy: The Games that Parties Play." In State of Nepal (8th Printing), eds. Kanak Dixit and Shastri Ramachandaran, 39-61. Kathmandu: Himal Books.

Wagle, Udaya R. 2009. "Inclusive Democracy and Economic Inequality in South Asia: Any Discernible Link?” Review of Social Economy 67 (3): 329-357.

Rajib Timalsina is lecturing at the Department of Conflict, Peace and Development Studies (CPDS), Tribhuvan University. He is also research co-director at Annual Status on Education Report (ASER) Survey in Nepal. He has published research papers exploring topics such as political culture, local and urban governance, security, peace politics, peace-tourism, and education policy. He is currently serving as a Governing Council Member for the International Peace Research Association (IPRA). Email: rajib.timalsina@gmail.com 